\title{
2
}

\section{An Overview of Water Quality Issues in Cambodia}

\author{
K.N. Irvine, T. Murphy, M. Sampson, V. Dany, S.J. Vermette, \\ and T. Tang
}

Cambodia is amongst the poorest countries in the world, ranking 130 of 175 countries in the 2002 Human Development Index, as reported by the United Nations (www.un.org.kh/rcsystem/). The GDP per capita in 2002 was US\$275 (www.state.gov/r/pa/ei/bgn/2732pr.htm). Life expectancy for men is around 54 and for women is 59 , which reflects various factors, including high infant mortality rate and low living standards. Mortality due to waterborne diseases in Cambodia is high and is a situation that could be improved through better sanitary conditions and education. Cambodia also faces challenges related to population demographics ( $43 \%$ of the population is aged 15 or less) and the decimation of the skilled/educated sector of society during the Khmer Rouge period of 1975-79 (Gottesman, 2003). Estimates of the genocide vary, but Kiernan (1999) suggested about 1.67 million people, or $21 \%$ of the population perished during this period.

Not only did the Khmer Rouge period exact a heavy toll on the Cambodian population, there also were major impacts on institutions and infrastructure within the country. Universities were closed, as were many primary and secondary schools. Although the Communist Party of Kampuchea (Khmer Rouge) had a Ministry of Education, there was little in

Irvine, K., T.P. Murphy, M. Sampson, V. Dany, S. Vermette and T. Tang. 2006. "An Overview of Water Quality Issues in Cambodia." Journal of Water Management Modeling R225-02. doi: 10.14796/JWMM.R225-02. (C) CHI 2006 www.chijournal.org ISSN: 2292-6062 (Formerly in Intelligent Modeling of Urban Water Systems. ISBN: 0-9736716-2-9) 
the way of an articulated education program. Typically, the focus of education was on the precepts of the Khmer revolution, with limited attention given to even basic literacy. As a result, the literacy rate for an entire generation of Cambodian children was quite low (Ayres, 2000; U.S. Library of Congress, countrystudies.us/combodia/35.htm; de Walque, 2004). Phyrun (1996) noted that one of the outcomes of the Khmer Rouge period was the "...complete destruction of institutions responsible for management of the country's resources, these include trained personnel, appropriate laws and regulations, enforcement capability, and government structures for development of environmental policies and co-ordination necessary for their implementation."

Despite this recent history, many reports have guarded optimism regarding socio-economic improvements for the country (e.g. United Nations, 2003) and it has been our observation that Cambodia is at a pivotal point in its history. It has the opportunity to move along the road of sustainable development, provided appropriate management decisions are made. In particular, Phyrun (1996) noted that the Royal Government of Cambodia (RGC) sees water as contributing to its priority of poverty alleviation, economic growth and food security. Water historically has played an important role in Cambodian society, for example, as evidenced by the magnificent hydraulic network and reservoirs constructed as part of the temple complex in Angkor between the eighth and $13^{\text {th }}$ centuries (Albanese, 2002; Kummu, 2003; Fletcher et al., 2003). Given the importance of water that the RGC has assigned to the country's future, the focus of this chapter is to provide an overview of water quality issues in Cambodia. This is not meant to be an exhaustive examination of the situation, but merely a starting point for discussion to help focus future management decisions. In providing this overview, we draw heavily upon the literature, as well as our own research projects and experience in Cambodia.

Our group, which includes faculty and students from Buffalo State, Royal University of Phnom Penh, scientists from Environment Canada's National Water Research Institute and, Resource Development International - Cambodia (RDIC) have ongoing independent and collaborative research projects related to water quality issues in Cambodia. Our collaboration began as a result of a mutual interest in arsenic contamination of drinking water. Dr. David Fredericks, a consultant for UNICEF in Cambodia, introduced the scientists from Buffalo State and Environment Canada to RDIC, one of the leading organizations in arsenic testing in the country. RDIC, a U.S.-based NGO (Non-Government Organization), works with the 
people of Cambodia on a variety of issues, ranging from health care, to sustainable agriculture, to water quality. An important component of the RDIC mission is public outreach and education. Other projects, beyond the arsenic issue, have started to evolve over a two year period. There is a great deal of basic research that needs to be done in Cambodia. We see two significant challenges to addressing these research needs. The first is that often there is a lack of coordination and sharing of data between projects sponsored by donor countries. Frequently, foreign scientists and personnel from different Cambodian government agencies are unaware of different ongoing projects, which is not optimal for resource sharing. Furthermore, information and data often are only available in agency reports that are difficult to access. We hope that this chapter goes some way in highlighting important water quality issues and reviewing them within a cohesive framework in a publication more readily available in the west. The second challenge is that of working in a developing, tropical country. Research support that we take for granted in the west is not readily available in Cambodia. Laboratory facilities are quite basic. At the present time there is limited capacity for the type of automated monitoring (both water quantity and quality) that we are accustomed to in the west. If existing monitoring equipment malfunctions, it is not possible to simply get a spare part the next day. Scheduling sampling can be a challenge, particularly when roadways in many areas become impassable during the rainy season. Still, it is important to meet these challenges using appropriate (in many cases, simpler) technology now, while at the same time providing education and training to inspire more refined research approaches in the future.

\subsection{Physical Setting}

Cambodia covers an area of $181,040 \mathrm{~km}^{2}$ in southeast Asia (Figure 2.1), which comparatively, is slightly smaller than the state of Oklahoma (www.odci.gov/cia/publications/factbook/geos/cb.html). Approximately $75 \%$ of the country's topography lies within the Tonle Sap Basin and Mekong Lowlands, with elevations generally less than 100 m (U.S. Library of Congress, countrystudies.us/combodia/35.htm).The Mekong Delta extends to the southeast from the Tonle Sap Basin and Mekong Lowlands, meeting the South China Sea at its terminus. Much of the Tonle Sap Basin and Mekong Lowlands consist of alluvium deposits which can reach a thickness of more than $200 \mathrm{~m}$ in the southeastern Svay Rieng province 
(Feldman and Rosenboom, 2001). Interspersed within the alluvium deposits are bedrock hills. The basin and lowlands regions are rimmed with mountain ranges to the southwest (Cardamom Mountains and the Elephant Range (elevations of 500-1800 m) and to the north (Dangrek Mountains). Higher land to the northeast and to the east merges into the Central Highlands of southern Vietnam.

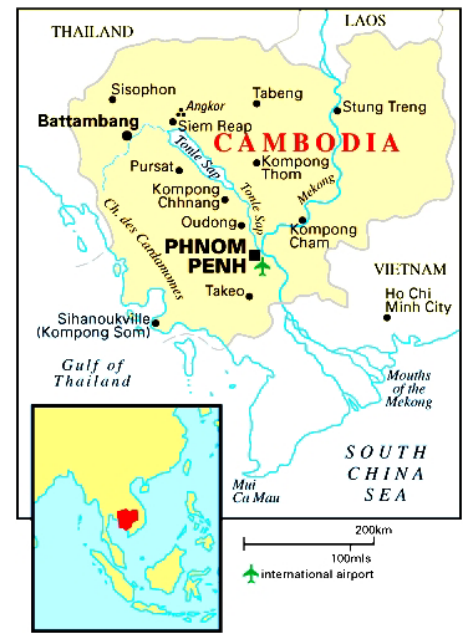

Figure 2.1 Cambodia with major cities and waterways.

Tonle Sap Lake (Figure 2.1) is the largest freshwater lake in southeast Asia, but because of the complex interaction with the Mekong River, its size varies considerably throughout the year. During the rainy season, flows are high enough on the Mekong River, so that flow reversal occurs in the Tonle Sap River, thereby providing a water source to the lake. During the dry season, the lake drains via the Tonle Sap River to the Mekong River. As such, the area of the lake varies from around $2,500 \mathrm{~km}^{2}$ in the dry season to $15,000 \mathrm{~km}^{2}$ in the rainy season, while depth increases from less than $1 \mathrm{~m}$ in the dry season to 7-9 $\mathrm{m}$ in the rainy season (Kummu et al., 2005). Comparatively, Lake Ontario has a surface area of $19,000 \mathrm{~km}^{2}$, but of course is much deeper (on average, $87 \mathrm{~m}$ ) (Yee et al., 1993). In addition to being an important cultural cornerstone, nearly 1.2 million people who live in fishing communes around the lake depend almost entirely on fishing for their livelihood. Annual fish yield ( $\mathrm{kg} / \mathrm{ha} / \mathrm{yr})$ from the lake is two to five times 
greater than the average for other Asian floodplain fisheries (Mekong River Commission, 2003; World Bank, 2003). Overall annual production recently was estimated around 230,000 tons, which represents $60 \%$ of Cambodia's annual commercial catch and provides $40 \%$ of Cambodia's total supply of protein (Kummu, 2003).

The climate of Cambodia can be considered a wet monsoon, with two distinct seasons. The rainy season starts in May and ends in October, as the Intertropical Convergence Zone (ITCZ) migrates north of Cambodia and moisture-laden air is drawn landward from the Indian Ocean. The dry season lasts from early November to April when the ITCZ migrates south of Cambodia and drier, cooler air flows from the northeast. There has been considerable difficulty in recovering historical meteorological records and during the period 1970-75, no data were collected (Eloheimo et al., 2002). Elohemo et al. (2002) collated available rainfall data and showed that between 1950 and 2000 (and excluding the years 1970-79), average annual rainfall from all stations ranged between 1,000 and 1,900 mm. However, the limited amount of rainfall data is exacerbated by the potentially large spatial variability of the rainfall. Kummu (2003), for example, examined recently collected rainfall data (post 1998) at 12 stations within and near the Angkor area (northeast end of Tonle Sap Lake) and concluded that average annual rainfall ranged between 1,050 and 1,850 $\mathrm{mm}$ and could exceed 2,000 $\mathrm{mm}$. Approximately $88 \%$ of this rainfall occurred in the rainy season. Furthermore, Kummu (2003) noted that precipitation at the Tonle Sap Lake shoreline and nearby highplain were only $64 \%$ and $50 \%$ of the precipitation in the Kulen Mountains to the north. To help address the limited spatial coverage of rainfall data our group recently has installed four tipping bucket gauges in Kandal province and one gauge in each of Kompong Speu, Kompong Chhnang, and Takeo provinces. Air temperatures are fairly uniform throughout the Tonle Sap Basin, with only small variations from the average annual temperature of $25^{\circ} \mathrm{C}$. Temperatures rarely fall below $10{ }^{\circ} \mathrm{C}$, but can exceed $38^{\circ} \mathrm{C}$ just before the start of the rainy season (U.S. Library of Congress, countrystudies.us/combodia/35.htm).

\subsection{Socio-economic Setting}

The population of Cambodia in 2002 was 13.04 million, with an annual growth rate of $2.4 \%$ (United Nations, 2003). Although the capital, Phnom Penh, has a population slightly greater than 1 million, the next largest cities 
are Sihanoukville $(155,700)$; Battambang $(140,000)$; and Siem Reap $(119,500)$ and the majority of the country's population $(84.3 \%)$ lives in rural areas. The principal ethnic group is Khmer ( $90 \%$ of the population), with smaller proportions of Vietnamese (5\% of the population) and Chinese $(1 \%$ of the population). Approximately $95 \%$ of the population is Theravada Buddhist (www.odci.gov/cia/publications/factbook/geos/cb.html ).

Although the tourism, manufacturing, and service sectors are growing, agriculture remains dominant, representing $28.4 \%$ of the GDP in 2001 and employing $80 \%$ of the working population (United Nations, 2003). The principal agricultural crop is rice, which accounts for $71 \%$ of the cultivated land in Cambodia. Smaller areas of field crops, fruits, and rubber plantations exist as well. Industrial production is dominated by garment and shoe manufacture, but also includes wood products, textiles, cement, rubber, and some food stuffs (www.state.gov/r/pa/ei/bgn/2732pf.htm). In 2000, Cambodia exported $76 \%$ of its garment production to the United States and $23 \%$ to the European Union.

The temples of Angkor, constructed between the eighth and $13^{\text {th }}$ centuries in the vicinity of the current city of Siem Reap are the major tourist attraction of the country. Designated a UNESCO World Cultural Heritage Site in 1992, the temple complex covers approximately $400 \mathrm{~km}^{2}$ and was the first capital of the Khmer empire (Albanese, 2002; United Nations, 2003). Tourist numbers have increased steadily at Angkor since the mid-1990s, more than doubling between 2000 and 2002 and reaching over 450,000 visitors (United Nations, 2003). With the increasing tourism opportunities has come relatively unplanned growth in the hotel sector and associated pressures on a limited city infrastructure in Siem Reap. Sihanoukville (Figure 2.1) is one of the few coastal areas in Cambodia having good beaches that can be exploited for tourism. Tourist development in this area has begun and likely will increase with the completion of a new, and relatively fast, two lane highway (4) from Phnom Penh.

As noted previously, Cambodia faces many economic challenges and because of past political uncertainties has had difficulty attracting foreign direct investment. In 2001, 58\% of the central government budget depended on donor assistance (www.state.gov/r/pa/ei/bgn/2732pf.htm). Despite these economic challenges, the United Nations (2003) noted that Cambodia now has one of the most open economies in the developing world and this approach may help improve economic conditions. 


\subsection{The Issues}

\subsubsection{Sanitation and Drinking Water}

Jalal (2003) noted that the World Summit on Sustainable Development (WSSD) held in Johannesburg in 2002 recognized water and sanitation are vital to protect human health and promote sustainable human settlements. Furthermore, the WSSD identified the goal of halving, by the year 2015, the proportion of people worldwide who are unable to reach or to afford safe drinking water or have access to basic sanitation. These goals also were in keeping with the Millennium Development Goals set by the United Nations in 2000. The WSSD emphasized the integration sanitation and drinking water issues, given the importance of their impacts on human health (Jalal, 2003). Following the WSSD recommendation, this section reviews issues of sanitation and drinking water together. Other specific water quality issues are examined in subsequent sections.

\subsubsection{Waste Water Disposal Practices}

The proportion of population in Cambodia that has access to sanitary waste disposal facilities is shown in Figure 2.2, as are data for other southeast Asian nations.

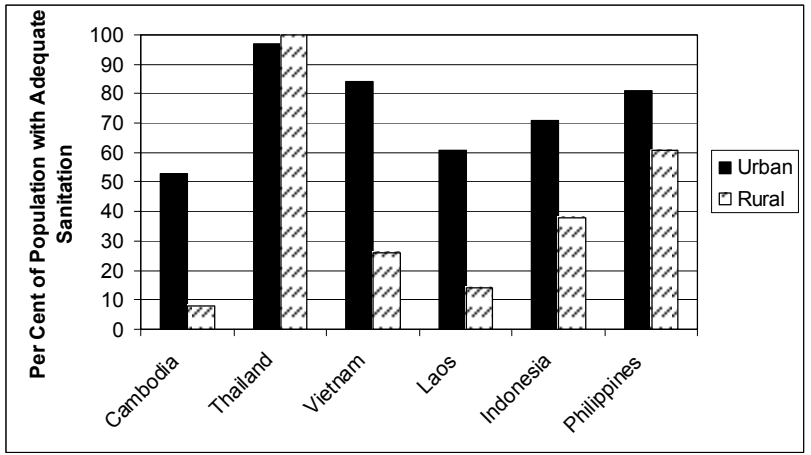

Figure 2.2 Population with adequate sanitation. Access to sanitation in urban areas includes connections to public sewers or household systems such as pit privies, pour-flush latrines, or septic tanks. Access in rural areas includes use of pit privies and pour-flush latrines. (from www.unicef.org/infobycountry; 2002 data). 
In general, Figure 2.2 shows that Cambodia has lagged behind its Asian neighbors in developing access to adequate sanitation facilities, but in examining waste water disposal practices in Cambodia, it also is essential to differentiate between the cities and rural areas.

The United Nations Food and Agriculture Organization (FAO) noted that a 1995 survey assessed water supply and wastewater quality in the main towns of Cambodia and found that most sewer systems were combined systems that were not well maintained and typically were not functioning properly (www.fao.org/ag/agl/aglw/aquastat/countries/cambodia/print1.stm). Phyrun (1996) indicated that most urban systems in Cambodia were constructed 25-45 years ago and consist of pour-flush or conventional flush toilets, sometimes draining to a septic tank (for large solids retention) and then to a street culvert. In most cases, the discharge from the sewers does not receive any further treatment.

Donor nations have begun to work with the Cambodian government to improve urban waste water handling, with mixed results. The Asian Development Bank provided funding to design and construct a sewage collection and treatment system with a capacity of $5,700 \mathrm{~m}^{3} \mathrm{~d}^{-1}$ for the city Sihanoukville, by June, 2005 (www.adb.org). Funding provided by the International Development Research Centre (IDRC), a Canadian public corporation, supported the construction and maintenance of a treatment plant in Battambang (Figure 2.1) in the mid-1990s. The treatment system consisted of three sedimentation ponds for primary treatment, two oxidation ponds for secondary treatment, and a fish pond and wetland. The plant provided treated water for irrigation purposes, sludge for fertilizer, aquaculture opportunities, and opportunities for students at the Royal University of Phnom Penh to research the health effects of agricultural use of raw sewage, economic benefits of using treated wastewater for irrigation, and treatment plant impacts on river water quality. Ultimately, the IDRC noted (http://web.idrc.ca/en/ev-40205-201-1-DO_TOPIC.html) that the plant effectively ceased operation once their funding ended. It was concluded that maintenance costs (apart from construction costs) of an off-site treatment plant with a drainage pipe infrastructure were too expensive for the residents of Battambang (or any other Cambodian city), without external assistance. Furthermore, it was concluded that the project did not succeed in strengthening institutional capacity at the national or provincial level since key personnel, trained for the project, left to work for other organizations. This is a common occurrence in Cambodia where government personnel may make US\$40 per month. 
The city of Phnom Penh is serviced by a combined sewer system, with approximately $160 \mathrm{~km}$ of (principally) concrete sewer pipe ranging in diameter from 0.3 to $1.5 \mathrm{~m}$ (Phyrun, 1996; JICA, 1999). Irregular invert slopes enhance sediment deposition and Phyrun (1996) indicated that such deposition ranges between 0.25 and $0.6 \mathrm{~m}$ in the $1 \mathrm{~m}$ diameter pipes. The city does not have a wastewater treatment plant, but most domestic sanitary flow and stormwater runoff is discharged to four wetlands located around the city for treatment. Muong (2004) estimated that on a daily basis, 55,600 $\mathrm{m}^{3}$ of domestic waste discharges to the three wetlands south of the city, Boeng Trabek, Boeng Tumpun, and Boeng Cheung Ek (Figure 2.3). A $30 \mathrm{~mm}$ storm of 24 hour duration also was estimated to discharge nearly 1 million $\mathrm{m}^{3}$ of stormwater flow to these three wetlands.
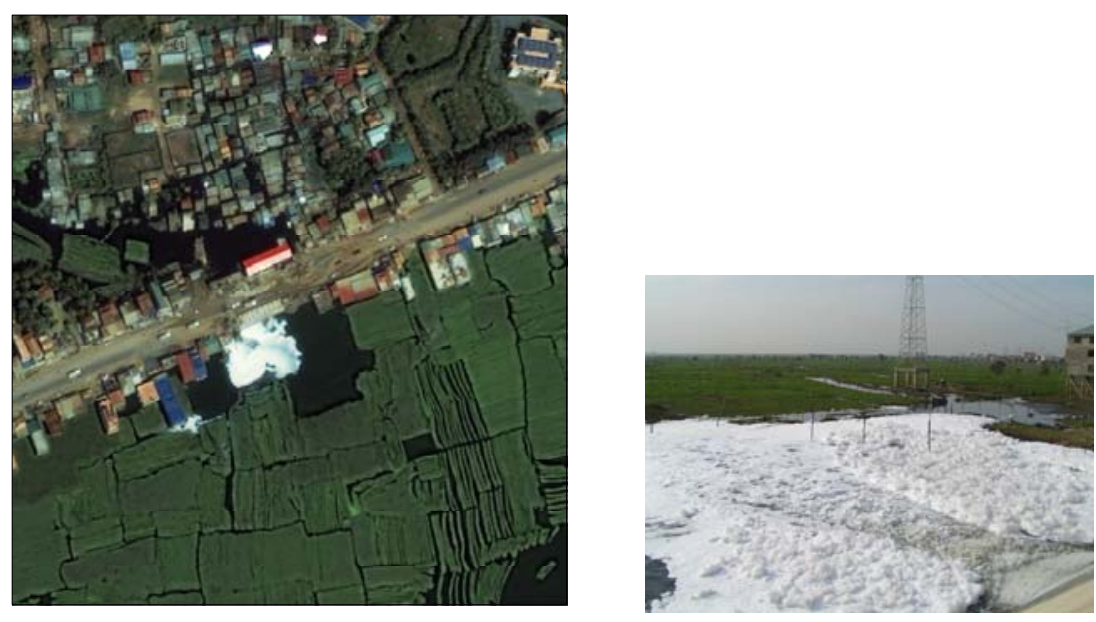

Figure 2.3 Ikonos satellite image of sewage discharge to Boeng Trabek wetland (left) and ground photo (right).

The wetland of Boeng Cheung Ek is the largest of the four wetlands, with a surface area ranging between 2,000 ha in the rainy season and 1,300 ha in the dry season; wetland inundation can be a problem during the rainy season as the Mekong River floods. The sewer system itself frequently cannot handle the high intensity Monsoon rains and street flooding in Phnom Penh is a common occurrence during the rainy season (Figure 2.4). Flooding of the sewer system presents potential health problems, but at the same time, designing for such intense rainfalls may not be practical. 

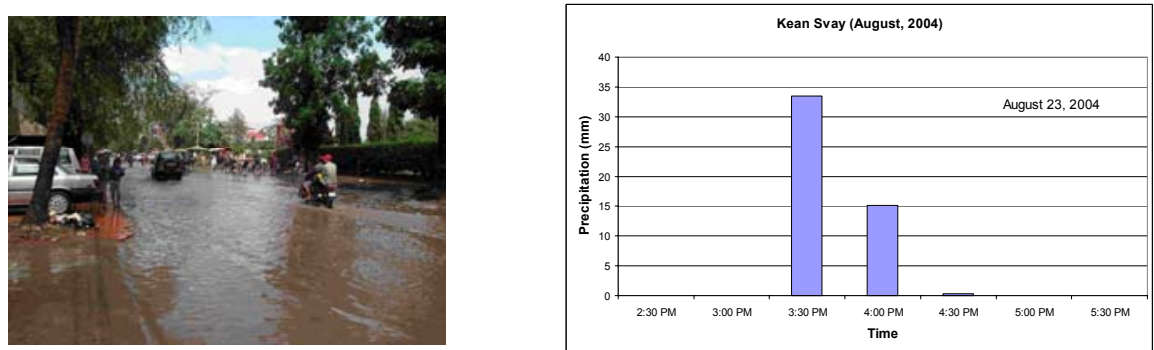

Figure 2.4 Street flooding in Phnom Penh (left) as the result of a typical monsoon rainfall, $48 \mathrm{~mm}$ in one hour (right).

The discharge of untreated industrial effluents to Boeng Tumpun and Boeng Cheung Ek also are a concern. Muong (2004) noted that based on Ministry of Environment records, 4.6 million $\mathrm{m}^{3}$ of industrial waste annually is discharged to these wetlands from more than 3,000 industrial firms. Industrial activity includes battery repair, paint manufacture, zinc and metal products, pulp and paper, textiles, and plastics production, as well as discharge from a municipal landfill. Local residents actively cultivate aquatic vegetables such as Morning Glory within the wetlands, as well as fish for commercial purposes and there is a concern about metals uptake for these food items (Little et al., 2003; Muon, 2004). However, there has been only limited testing of the wetland soils for metals levels. JICA (1999) sampled four sites within the wetlands and found the mean level of $\mathrm{Cd}$ to be $1.55 \mathrm{mg} / \mathrm{kg}$ and the mean level of $\mathrm{Cr}$ to be $14 \mathrm{mg} / \mathrm{kg}$. Both of these results indicate a level of contamination may exist that should be examined in more detail. Furthermore, the JICA (1999) report is the only published study that has conducted any sewer sampling. The JICA (1999) study collected water samples at 6 locations in sewers and 5 locations treatment wetlands, twice during the dry season and twice during the rainy season. Analytes included fecal coliform, dissolved oxygen, turbidity, conductivity, $\mathrm{pH}, \mathrm{COD}$, and BOD, but metals levels were not reported. Fecal coliform levels in the sewers ranged between 3,600 and 4,600,000 per $100 \mathrm{~mL}$ and in the wetlands between 21,600 and 4,600,000 per $100 \mathrm{~mL}$. Dissolved oxygen levels in the sewers ranged between 0.1 and $4.6 \mathrm{mg} / \mathrm{L}$ and in the wetlands between 0.1 and $7.8 \mathrm{mg} / \mathrm{L}$. BOD 5 levels in the sewers ranged between 8 and $76 \mathrm{mg} / \mathrm{L}$ and in the wetlands between 7 and $46 \mathrm{mg} / \mathrm{L}$. The data are limited, so it is not possible to draw conclusions regarding the effectiveness of the wetlands in treating the sewage. 
Figure 2.2 shows that rural access to adequate sanitation is considerably lower than access in urban areas. Mukherjee (2002) noted that the rural population traditionally has used rice fields, banana groves, and waterways (rivers, lakes, ponds) for defecation and that funding for sanitation and hygiene promotion has been a much lower priority than major construction of public infrastructure. In conducting a detailed review of the sanitation situation in rural areas of two provinces, Battambang and Kompong Spue that had water seal toilets, Mukherjee (2002) concluded:

- Wealthy households (as defined by their own village criteria) had a $77-100 \%$ access rate to toilet facilities.

- Poor households (which made up $54 \%$ of the population) had $3-26 \%$ access rate to toilet facilities. Poor households found it difficult to contribute the one time US\$8 construction cost when wages for a farm laborer were $<\$ 1$ per day.

- Motivating factors to build household latrines included previous exposure to such facilities; access to towns to get sanitation supplies; diminishing forest cover/rice fields available for defecation; awareness of good hygiene; financial capability.

- Apart from the inability to pay for construction, barriers to the widespread establishment of latrine use included poor access to water; where latrines were provided for free there was no sense of ownership or need to maintain them; projects that did not include a hygiene education component were much less successful.

- Villagers identified numerous benefits to the use of latrines, including a clean and smell-free house; safety (no need to go into the jungle with fear of bandits or snakes); convenience; disease prevention; privacy; and economic benefits (e.g. fewer days lost to work because of sickness).

Jalal (2003) also noted several projects in developing areas of Asia, including Pakistan and Myanmar, where latrine construction has successfully improved sanitary conditions. In particular, Jalal noted that to be successful, these projects had to overcome four barriers: i) the psychological barrier related to the population's belief that developing a sewage system is the duty of the government and should be available free of 
charge; ii) the economic barrier posed by the high cost of the conventional system designed to specifications developed in wealthy nations; iii) the technical barrier requiring local residents and their contractors to have the skills necessary to construct an underground sanitation system; iv) the sociological barrier requiring organizational skills for community collective action with full public participation. These barriers were common to those issues identified by IDRC in their treatment plant project for Battambang.

As noted by Mukherjee (2002) barriers to widespread establishment of latrines include construction cost and access to water. Resources Development International - Cambodia (RDIC) currently is testing a new program that uses an alternating two pit latrine design. Elimination of the pour-flush system greatly reduces or eliminates the need for water as well as reducing the size of the pit needed for waste. Relatively low cost (approximately US\$12) and ease of construction of the system also play a major role in the design. The new system is constructed from locally available materials and requires no skilled labor for construction which enhances the probability of self propagation. The project is being tested in two villages approximately $12 \mathrm{~km}$ east of Phnom Penh in a highly populated area where $54 \%$ of the homes do not use latrines of any kind. An educational program prior to the introduction of the latrines made acceptance levels high. Continued education on proper use and maintenance is yielding positive results. The system also hopes to introduce in a practical way the use of human excrement as fertilizer. Traditionally Khmer have been very resistant to handling human excrement.

\subsubsection{Drinking Water}

During the period 1979 through 1994 construction of water supplies focused mainly on emergency provisions in areas where security conditions were favorable (Ministry of Rural Development, 2002). More recently, the focus has shifted from emergency relief to long term development.

Feldman and Rosenboom (2001) conducted the first general assessment of drinking water quality for Cambodia. This study initially sampled 94 urban and rural water sources in 13 of Cambodia's most densely populated provinces and analyzed the samples for a variety of metals, 40 different organochlorine and organophosphate pesticides, nutrients, and other conventional parameters. Samples were analyzed at the Queensland Department of Natural Resources laboratory in Brisbane, Australia. Bacteria analysis specifically was not done because it was recognized that biological 
contamination frequently exists in untreated water supplies throughout Cambodia, while chemical data did not exist. Cambodians use both surface and ground water for drinking water sources (Table 2.1) and samples therefore were collected from a variety of sources. Feldman and Rosenboom (2001) noted that in the past 10-15 years there has been an increasing trend in rural Cambodia to supply water via either handpump wells or shallow, hand dug (open) wells to reduce the risk of infection through waterborne disease.

Table 2.1 Sources of drinking water (from National Institute of Statistics, 2000)

\begin{tabular}{lcc}
\hline \multicolumn{1}{c}{ Source } & $\begin{array}{c}\text { Percent of Urban } \\
\text { Households }\end{array}$ & $\begin{array}{c}\text { Percent of Rural } \\
\text { Households }\end{array}$ \\
\hline Piped into dwelling & 32.4 & 0.7 \\
Public tap & 1.7 & 0.3 \\
Open well in dwelling/yard & 6.0 & 10.0 \\
Open public well & 10.1 & 22.9 \\
Protected well in dwelling/yard & 3.4 & 1.4 \\
Protected public well & 1.5 & 2.1 \\
Tubed well or borehole in dwelling/yard & 7.7 & 8.5 \\
Tubed public well or borehole & & \\
Spring & 4.7 & 12.5 \\
River/stream/pond/lake/dam & 0.6 & 0.8 \\
Rainwater & 10.0 & 27.0 \\
Tanker truck/water vendor & 10.8 & 8.0 \\
Bottled water & 8.7 & 2.6 \\
Other & 0.2 & 0.1 \\
& 2.5 & 3.4 \\
\hline
\end{tabular}

Note: dry season and rainy season data from original source were averaged for this table

Pesticides were not detected in any samples reported by Feldman and Rosenboom (2001). Some constituents in groundwater (iron, manganese, sodium, chlorides, hardness) were high enough to impact taste but are not of great health concern. Nitrite levels were higher than United Nations World Health Organization (WHO) guidelines for one sample and nitrate was higher for three samples. Levels of barium, chromium, lead, molybdenum, and selenium exceeded WHO guidelines in one or two locations each. Fluoride exceeded WHO guidelines in two samples but the mean concentration of all samples was low at $0.4 \mathrm{mg} \mathrm{L}^{-1}$. The most important finding of the initial round of sampling was the elevated levels of arsenic for 
samples from five provinces. Samples in Kandal province had some of the highest levels (up to $504 \mu \mathrm{g} \mathrm{L}^{-1}$ ) of arsenic; the current WHO guideline is 10 $\mu \mathrm{g} \mathrm{L}^{-1}$. An additional 21 samples were collected in the province and these confirmed high levels existed.

\subsubsection{The Special Case of Arsenic}

Arsenic contamination in Cambodian groundwater appears to have a similar natural source as in Bangladesh. Arsenic appears to descend down the Mekong River from natural processes in the Himalayan Mountains. Water management in Cambodia has some parallels to Bangladesh. To avoid bacterial contamination in surface water, wells were dug in both Bangladesh and Cambodia. In Bangladesh, thousands of people are suffering from arsenic related diseases and millions have some risk of arsenic poisoning (Paul and De, 2000; Safiuddin and Masud, 2003). Epidemiological studies implicate arsenic with diseases such as hyperkeratoses, peripheral vascular disease ('blackfoot disease'), skin, lung and bladder cancers, diabetes, anemia, and disorders of the immune, nervous and reproductive systems (Murphy and Guo, 2003; Oremland and Stolz, 2003; Pavittranon et al., 2003; $\mathrm{Yu}, 2003)$. It also interferes with hormones making it a potent endocrine disrupter (www.epa.gov/safewater/ars/arsenic.html). The current arsenic contamination of drinking water in Bangladesh overshadows other sites ( $\mathrm{Yu}$, 2003). The difference between Bangladesh and Cambodia arsenic is mainly related to timing. In the 1960s and 1970s, UNICEF drilled 4 million wells in Bangladesh (Stute and Zheng, 1999) but the history of most wells in Cambodia is about 10 years. Many cancers take 15 years to develop. Simple extrapolation would indicate that without intervention in water management, Cambodia will experience the same problems as Bangladesh.

There are several ongoing studies in Cambodia related to arsenic but the full extent of the problem in Cambodia is not well resolved. Agusa et al. (2002) found that groundwater wells in Kandal province in Cambodia contained an average of $178 \mu \mathrm{g} \mathrm{L}^{-1}$ of arsenic. RDIC has sampled over 4600 wells. Their analysis indicates that some areas near the Mekong River, especially in Kandal province have an average of $235 \mu \mathrm{g} \mathrm{L}^{-1}$ (mean of subset of 1600 water supplies) of arsenic in wells. This simple summary underscores the risks. Many wells do not contain any arsenic and where it is found, it can exceed $500 \mu \mathrm{g} \mathrm{L}^{-1}$. Figure 2.5 presents a detailed image of arsenic contamination of wells in Kean Svay village in Kandal province. The variation in arsenic reflects the type of well, and perhaps local variation 
in total arsenic minerals and processes that dissolve the arsenic. Discharge of organic wastes such as sewage resulting in reducing conditions is the most likely mechanism for enhanced dissolution of arsenic in minerals but arsenic dissolution could be mediated by use of phosphorus such as used in fertilizers that could displace arsenic from adsorption sites too.

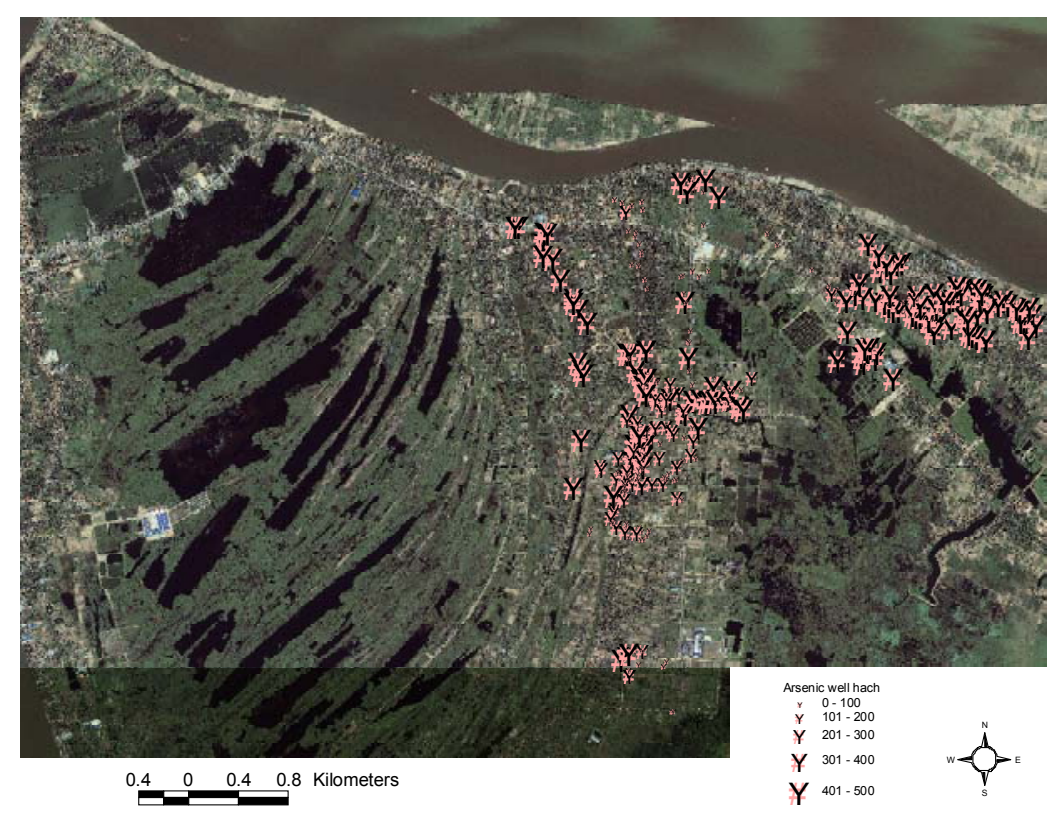

Figure 2.5 Arsenic concentrations, $\mu \mathrm{g} \mathrm{L}^{-1}$ in groundwater samples from Kean Svay, near Phnom Penh.

The concerns with human health are complicated by the co-occurrence of multiple health issues. Arsenic toxicity is more serious with people with malnutrition (Mitra et al., 2002) and malnutrition affects about half of Cambodian children (www.unicef.org/infobycountry/cambodia.html). Also arsenic weakens the immune system and makes infections by bacteria more likely (Bishayi and Sengupta, 2003). Bacterial infections are the main cause of death in Khmers. Similarly, Gerdsen et al. (2000) have shown that arsenic can enhance papillomavirus as a co-factor in the pathogenesis of premalignant arsenic-induced skin tumours. Recent studies continue to find new linkages between arsenic and health problems as diverse as fetus death 
(Chakraborti et al., 2003) and chronic cough and bronchitis (Milton et al., 2003). Simply, arsenic attacks multiple organs and it would be expected that in areas where arsenic is enriched in the groundwater of Cambodia, many common diseases would be enhanced.

Although it is likely that the arsenic contamination in Cambodia is natural, the situation is unresolved. With a lack of data, the alternative hypothesis that arsenic comes from mines cannot yet be discredited. Mining is a common source of arsenic pollution (Zhang, 2003; de Esparza, 2003). There is a long history of mining in Yunnan, China, the headwaters of the Mekong River but there are little data on arsenic release. Gejiu in Yunnan has been mined for centuries and arsenic and associated cancers are well documented (Sun, 1987). Gejiu drains into the Red River into Vietnam where arsenic contamination exists in groundwater (Berg et al., 2001).

Recently pollution from small gold mines in Cambodia is being speculatively linked to mortality of the Irawaddy dolphins. In 2004, 19 of 80 dolphins died in the Mekong River (Gilbert, 2005, Personal communication. Wildlife Conservation Society, Phnom Penh). Arsenic has not been commonly proposed as responsible for the high dolphin mortality, but Agusa et al. (2002) did find high concentrations of arsenic in hair in humans in the area where the dolphins die (Kratie). It is odd in that the groundwater used for drinking there has little arsenic. Sotham (2004) speculates that mercury from gold mines may be responsible for the dolphin mortality. These gold mines are primitive. Some use mercury for gold extraction but there are no data yet to resolve if these gold mines might be responsible for the dolphin mortality. If mercury from gold mines or other sources were responsible for the dolphin mortality, the damage to tens of thousands of people who rely upon fish as their main protein source would be substantial.

\subsubsection{Alternative/Appropriate Technology for Safe Drinking Water}

Jalal (2003) suggested that in addressing issues of safe drinking water in Asia, it is important to develop and transfer low-cost technologies and as an example he described a rainwater harvesting program in India. After a site visit to the province of Siem Reap in 2004, the Rotary Club's Pure Water for the World program concluded that their bio-sand filters could be manufactured in Cambodia and were suitable for local use (www.middletownrotary.net/cambodia.htm ). First Water and OXFAM began a trial in 2002 on the use of ceramic water filters in Takeo province, 
south of Phnom Penh. The drip filters were distributed to 100 households in 11 villages. A follow-up survey in 2003 concluded that the filters were wellaccepted by the households ( $5-10 \%$ were not using their filters); to maintain the units villagers were willing to pay the US\$4-5 for a new filter, $\$ 0.25-0.5$ for a new candle, and $\$ 0.25-\$ 1.25$ for a new tap; benefits cited by the participants included clearer water, reduced cost and effort finding wood for boiling, improved personal health (including children having less diarrhea and fever) (www.firstwater.info/media/Takeo\%20Province.html).

Traditionally Cambodians collect rainwater from their roofs to use for bathing and consumption. A National Institute of Statistics (2000) survey showed that urban use of rainwater for consumption rose from $1.7 \%$ in the dry season to $19.8 \%$ in the rainy season. In rural areas, rainwater use for drinking rose from $1.0 \%$ in the dry season to $14.9 \%$ in the rainy season. Surveys done by RDIC suggest Cambodians prefer rainwater for drinking above other sources. Unfortunately existing rainwater harvesting practices are not very good, with problems that include:

- insufficient storage capacity

- containers become breeding ground for mosquitoes which carry dengue fever

- water is removed by dipping a bowl into the storage container which is a source of pathogenic contamination

- Open top allowing dust and other contaminants to freely enter.

In April 2004 RDIC tested water from 150 traditional water jars randomly selected from two separate villages east of Phnom Penh. All of the jars tested positive for high levels of $E$. coli and mosquito larvae were observed in 82 percent of the jars. This area was selected for study because the groundwater is highly contaminated with arsenic and rainwater harvesting is practiced by most of the population.

For rainfall harvesting to be successful, low cost easy to construct storage tanks were needed for both schools and individual homes. Schools were targeted before individual homes so that children could disseminate information and experiences to family and friends. Schools with an average student population of 800 were targeted with Ferro cement cylindrical tanks with a capacity exceeding $30 \mathrm{~m}^{3}$ (Figure 2.6). These tanks were constructed at schools which have a very large roof collection area. Collection of the water at a school is quite easy, but what is more difficult is the distribution to students. RDIC approached this problem by using treadle pumps with 
pressure head which allows students to pump water to different distribution points. Each distribution point has its own ceramic water purifier. An educational program was developed which utilized music and puppets. The programs promoted the safe handling and storage of rainwater for human consumption. Each child was given a drinking water bottle to carrying clean water at school as well as to take home as part of the program.

Systems for individual homes were targeted next by the project. RDIC developed a spherical tank called the earth tank; this name was chosen for cultural reason to promote acceptance (Figure 2.6). The tank comes in two sizes $\left(4.2 \mathrm{~m}^{3}, 1.7 \mathrm{~m}^{3}\right)$. Tanks were made of Ferro cement, which is formed on molds largely composed of dirt with a simple metal frame. The tank design allows for easy cleaning, access to the water through a faucet, as well as an attractive appearance. Tanks are enclosed to limit contamination and to prevent them from becoming a breeding ground for mosquitoes. Currently there are more than 300 tanks being tested in the field. Results from bacterial testing on 50 tanks in use for 4 months or longer showed significantly lower levels for $E$. coli, with several tanks testing absent of all $E$. coli. An educational program was developed which promotes safe handling of the water as well as conservation. Conservation is an important concept in this program because the $4.2 \mathrm{~m}^{3}$ is not a sufficient quantity of water for bathing and washing, but is sufficient to meet the needs for drinking and cooking for a normal family of six.

Many areas of Cambodia have abundant supplies of surface water. Traditionally surface water has been used for drinking. Unfortunately, most of the surface water has been contaminated and is unsafe to drink without proper treatment. Therefore, RDIC began experimenting with different methods for point of use treatment of drinking water. The first method used was a simple sand filter couple with a low cost UV zap chamber produced from locally available materials. The UV light bulb was powered by a 12 DC car battery which commonly are used in rural areas for lighting and running small appliances. The simple slow sand filter was used to remove solids from the source water and the UV light was used to deactivate bacteria and other pathogens. Like many other technologies the system worked well when maintained, unfortunately most systems were not maintained well by villagers and schools. Despite education people often failed to turn on the light and many used the battery to run their TV set instead of the UV light. The technology did find some success in more organized environments such as orphanages and medical centers. 

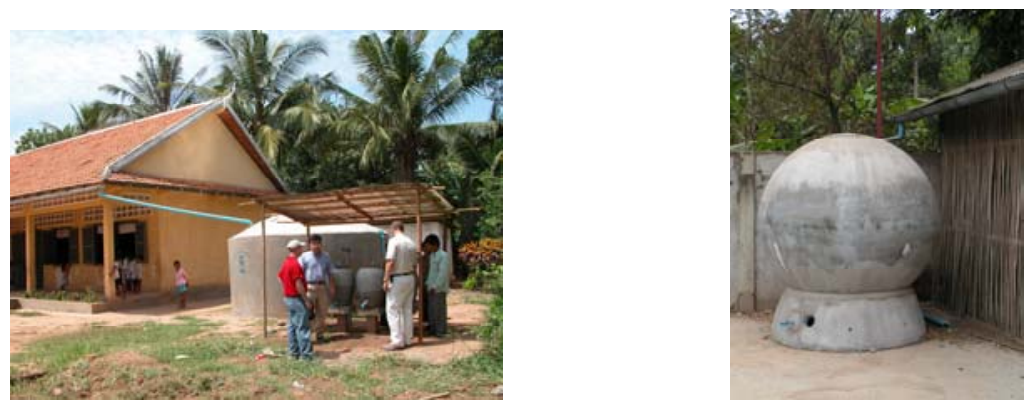

Figure 2.6 RDIC rainwater harvesting systems at a school (left) and home (right).

The use of ceramics in filtration has been known for thousands of years, especially in China. In recent years the organization Potters for Peace has promoted the use of ceramic filters throughout the developing world. RDIC met with a representative from Potters for Peace and decided to develop a factory in Cambodia, which did not use traditional potters, but instead used simple mechanical presses to produce a ceramic filter. The shape of the filter is that of a flower pot. The flower pot shaped filter with a capacity of $11 \mathrm{~L}\left(0.011 \mathrm{~m}^{3}\right)$ fits snuggly into a food grade plastic receptacle (Figure 2.7). Source water is poured directly into the filter and as the water seeps through the walls of the filter it is collected and safely stored in the receptacle which has a faucet near the bottom edge. The flow rate of 2 liters $\left(0.002 \mathrm{~m}^{3}\right)$ per hour is sufficient to meet the needs of individual families. The ceramic insert also is impregnated with silver to enhance bacterial removal. Advantages of the ceramic filter include:

- produced locally by nationals,

- produced from local resources,

- low production cost,

- little maintenance required, and

- sales of the filter can make the factory selfsustainable.

In the lab and the field the filter has proven to be effective at removing most pathogens, the exception being viruses which are currently under investigation. Field work also has shown that education in proper use of the filters is vital. Problems encountered with the filter in the field include:

- shipping cost, 
- ceramic insert is fragile especially when saturated with water,

- contamination of the receptacle, and

- contamination of the faucet.

The ceramic filter has shown great promise in Cambodia. Two other organizations recently built factories and a strategy is under development to make the filters available to all parts of the country.
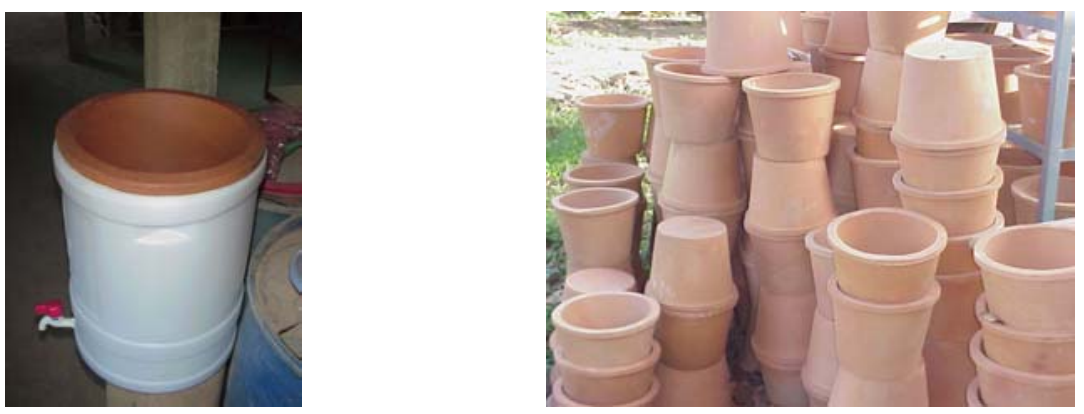

Figure 2.7 RDIC water filter system (left) and ceramic filter inserts (right).

\subsubsection{Agriculture and Aquaculture}

There are several potential issues related to current and future agriculture and aquaculture practices that may have an impact on water quality. The Environmental Justice Foundation (2002) identified several concerns regarding pesticide use in Cambodia. First, a survey in 2000 found that $33 \%$ of the products available in Cambodian markets were classified as WHO Class I (highly or extremely hazardous to human health), including mevinphos, monocrotophos, dichlorvos, and methyl-parathion; DDT and chlordane also were available. A different study, done in Takeo province, similarly found $32 \%$ of the pesticides used by surveyed farmers were in the WHO Class I (Chenda et al., 2002). Although this class of pesticides is banned under Cambodian law, weak enforcement contributes to continued market presence. There has been a suggestion that Cambodia has become a dumping ground for pesticides banned in more developed countries. Monirith et al. (2000) sampled fish in two coastal locations in Cambodia and three inland river locations; green mussels were sampled from six coastal locations. The samples were analyzed for organochlorine pesticides, HCB, 
and PCBs. DDT and its metabolites were the predominantly detected compounds in the fish and mussel samples. The mean DDT level in fish from Kampong Chhnang (Tonle Sap River at the southern end of Tonle Sap Lake) was $450 \mathrm{ng} \mathrm{g}^{-1}$ (fat wt) as compared to a mean of $290 \mathrm{ng} \mathrm{g}^{-1}$ at Kampong Cham (Mekong River upstream of Phnom Penh) and $100 \mathrm{ng} \mathrm{g}^{-1}$ in Kandal province (Mekong River near Phnom Penh). Monirith et al. (2000) concluded these results show the current use of DDTs in the Tonle Sap Lake region for agricultural and aquacultural purposes. In the case of aquaculture, DDT has been used to control parasites in caged fish cultures. Although these spatial trends were detected, Monirith et al. (2000) also compared their results with those for other Asian and Oceanic countries and concluded that organochlorine residue levels in fish and mussels from Cambodia typically were lower. Chenda et al. (2002) noted that farmers in two villages surveyed in Takeo province observed dead fish in irrigation canals after fungicide applications and that domesticated ducks also have died after feeding in rice fields.

Data from the FAO (Figure 2.8) show that between 1989 and 1998, pesticide imports to Cambodia doubled, but remained level between 1998 and 2002. The study in Takeo province (Chenda et al., 2002) indicated $87 \%$ of the 120 farmers surveyed used pesticides and that there has been a steady increase in pesticide use from 1993 to present.

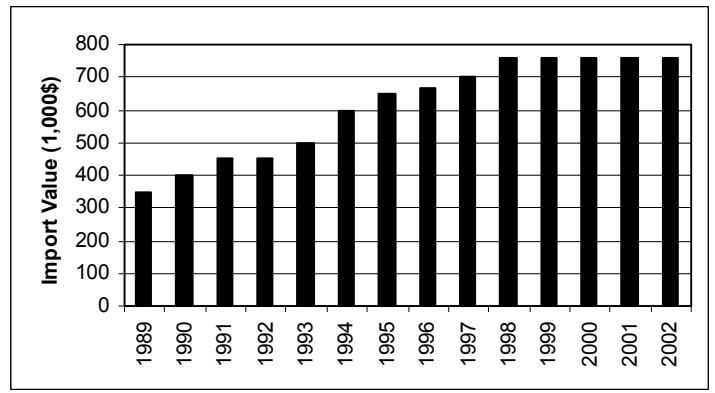

Figure 2.8 Annual pesticide imports to Cambodia (http://faostat.fao.org).

Additional concerns identified by the Environmental Justice Foundation (2002) were related to labeling. The majority of pesticides are imported from either Vietnam or Thailand and instructions for application and safety are in 
a language that cannot be read by vendors or farmers. Frequently there is an ignorance about the health risks associated with pesticide use, the appropriate pesticides to use for particular crops, and timing of use (e.g. spraying within several days of harvest). The Environmental Justice Foundation (2002) outlined a program of Integrated Pest Management that potentially would reduce Cambodian use of pesticides.

Our group conducted a pilot survey of 20 farming families in the Stung Chinit watershed near Kampong Thom (Figure 2.1) in May, 2005. The survey examined topics including cropping practices (type grown, yield, time of planting and harvesting, economic value of crop), fertilizer and pesticide use and storage and irrigation practices. The survey also identified socio-economic characteristics (in rural Cambodia, relative wealth depends on other factors than annual money income) and drinking water and sanitation practices. The surveys were conducted through RDIC interpreters experienced in rural outreach. Analysis of the surveys is ongoing, but preliminary results (Justice and Irvine, 2005) showed that chemical fertilizers are used mostly by higher socio-economic level farmers while natural (manure) fertilizers are used by lower socio-economic level farmers. Proper chemical fertilizer application based on N-P-K ratios and soil types appears to be non-existent. Fertilizer selection is based on what neighbors use, what is least expensive, and what is available from the market. Most farmers indicated that their pesticide use and application methods were "learned from neighbors". This type of diffusional learning is common in Cambodia. Market dealers also provided information on pesticide use. Personal protection equipment was rarely worn while applying pesticides, even though the majority of farmers indicated some type of ill-health after applying the pesticides. Fertilizers and pesticides typically are stored in or under homes where the entire family eats and sleeps. Environmental impacts, mainly in the form of fish kills, were observed by some farmers after applying pesticides. Finally, our survey was consistent with the findings of the Environmental Justice Foundation (2002) in that the majority of pesticide labels were printed in Vietnamese or Thai.

It has been generally accepted that drinking water is the greatest concern with exposure to arsenic. This belief is based on studies that have shown that often the arsenic in food is an organic form that at times has minimal toxicity whereas arsenic in water almost always is present in a toxic form (Abernathy et al., 2003). In part, this important concept was based a few studies. The limitation had been largely associated with the analysis of complex forms of arsenic that requires more advanced instrumentation such 
as HPLC-ICP-MS (Le et al., 2004). In the last few years, this concept of arsenic in food has changed. Recently, the U.S. EPA (2003) released a report stating that food can be an equal source of arsenic as water. Guo (2003) found that yams and rice in Taiwan had significant concentrations of inorganic arsenic. The greatest concern with bioaccumulation of inorganic arsenic into rice exists now in Bangladesh (Abedin et al., 2002a; Abedin et al., 2002b). Abedin's team showed via speciation of arsenic using HPLCICP-MS that the predominant species present in rice straw was arsenate followed by arsenite and dimethylarsinic acid (DMAA). Meharg and Rahman (2003) propose that even with new arsenic-free supplies of water, arsenic in food would continue the arsenic disaster in Bangladesh. The soils there have been poisoned by use of arsenic rich groundwater to grow rice in the dry season. As expected, the quantity of rice production is also reduced by use of arsenic-rich groundwater (Abedin and Meharg 2003). The factors that influence arsenic bioaccumulation are not fully characterized. The history of irrigation must be important.

Ongoing studies of arsenic bioaccumulation into foods in arsenic-rich areas in Cambodia by Murphy's team are incomplete, but the risks appear to be less than those presented by drinking water. The highest amounts of arsenic were found in bivalves (mean $7.98 \mu \mathrm{g} \mathrm{g}^{-1}, \mathrm{n}=6$, from burrow pits) and gastropods (Pomacea canaliculata, mean $6.29 \mu \mathrm{g} \mathrm{g}^{-1}, \mathrm{n}=6$, from natural wetlands). Much of this arsenic is present as non-toxic arsenobetaine. These arsenic levels are quite typical of marine animals and much higher concentrations have been reported in marine food collected from apparently normal areas (Edmonds and Franecsconi, 1993; de Gieter et al., 2002).

FAO statistics (http://faostat.fao.org) for 2002 show that $7.3 \%$ of arable land in Cambodia is irrigated. Irrigation increased marginally between 1989 and 2002, but Sinath (2002) noted that it is the goal of the Royal Government of Cambodia to increase the proportion of irrigated land to $20 \%$. While the source of much of this water may be constructed reservoirs, groundwater has been considered. Potential groundwater sources should be tested for arsenic levels before being exploited for irrigation.

\subsubsection{Water Quality in the Mekong, Tonle Sap, and Bassac Rivers near Phnom Penh}

In July, 2004, our group began to evaluate water quality in the Mekong, Tonle Sap, and Bassac Rivers near Phnom Penh. The kick-off of this work included a workshop on water quality sampling and analysis and GIS 
applications for personnel from the Ministry of Rural Development; Ministry of Industry, Mines and Energy; Ministry of Environment; faculty from the departments of Environmental Science and Geography, Royal University of Phnom Penh; and personnel from UNICEF (Irvine et al., 2004). As part of the workshop, and in subsequent efforts, samples were collected at five sites (Figure 2.9) and analyzed using a kit approach.

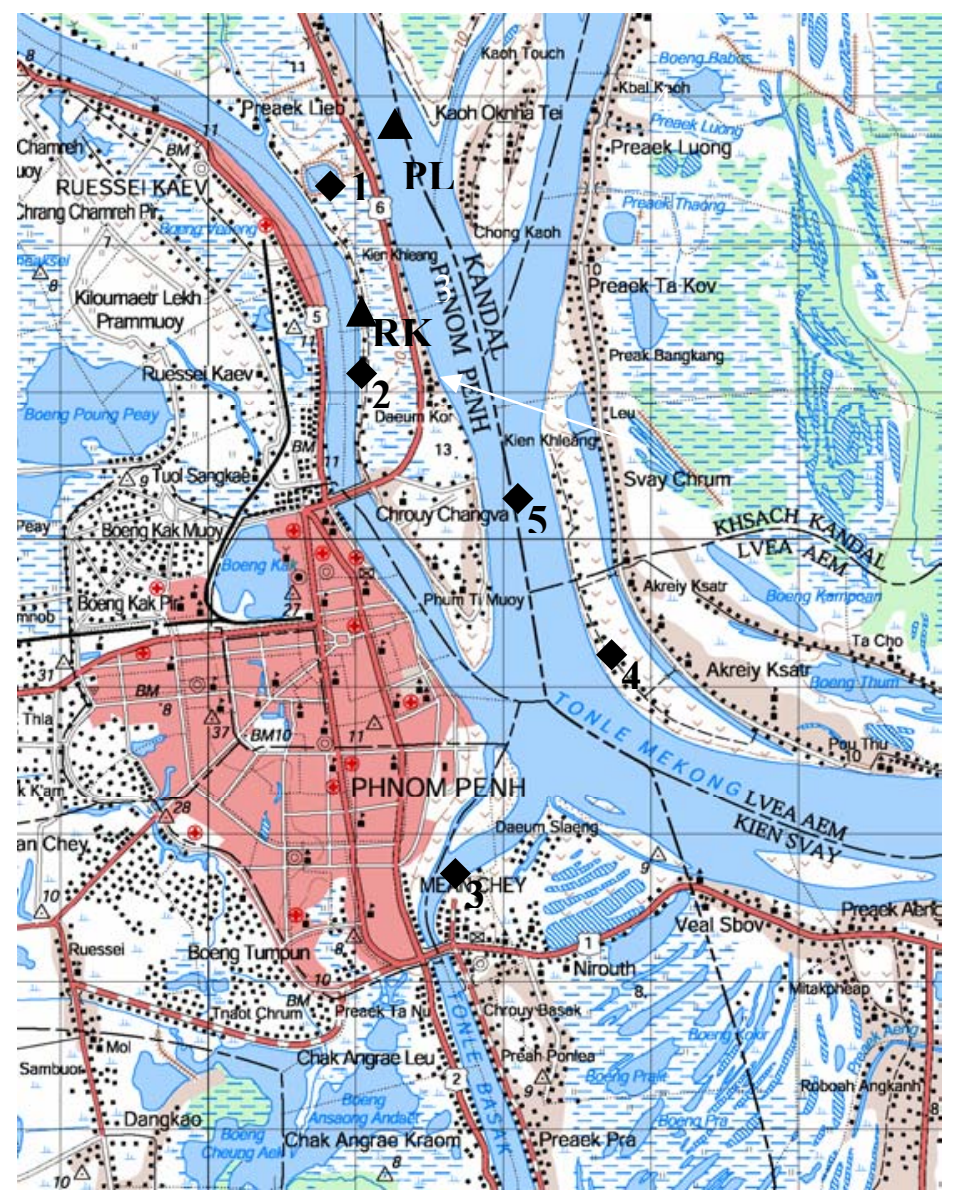

Figure 2.9 Hydrolab ( $\boldsymbol{\Delta}$ ) and water quality ( $\bullet$ sampling sites. Hydrolab site RK is Russey Keo on the Tonle Sap River and PL is Preak Leap on the Mekong River. 
The kit approach was developed under Buffalo State's Aquanauts Program (http://www.buffalostate.edu/orgs/aqua/). Kit parameters included dissolved oxygen, $\mathrm{BOD}_{5}, E$. coli, nitrate, phosphate, $\mathrm{pH}$, hardness, temperature, and Secchi depth (or turbidity). Instructions for the kits were translated into Khmer and laminated to facilitate use in the field. The water column was profiled to a depth of $8 \mathrm{~m}$ using a Hydrolab Datasonde 4a. Hydrolab Datasonde 4a's subsequently were installed at two locations (Figure 2.9) and programmed to record dissolved oxygen, turbidity, $\mathrm{pH}$, temperature, and conductivity at 15 minute intervals.

Results of the July, 2004 and January, 2005 sampling are shown in Table 2.2. A comparison of parameters measured by the kit approach and the Hydrolab showed overall good agreement (Figure 2.10). The larger difference in turbidity probably is the result of converting Secchi disk depths (kit approach) to an NTU value.

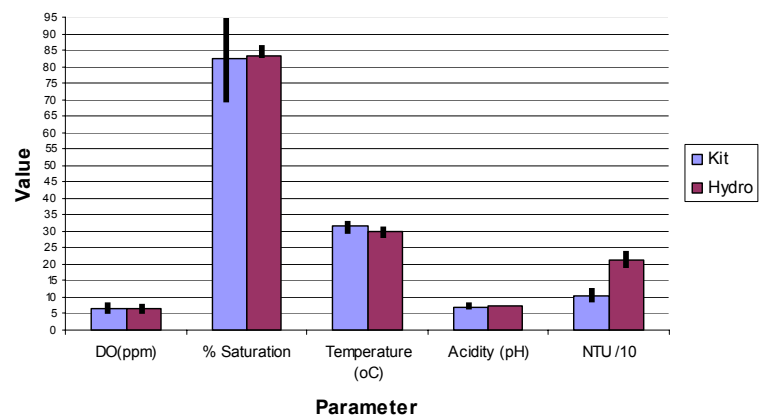

Figure 2.10 Aquanauts kit results versus Hydrolab (1m depth) results for the five sample sites. Mean values are shown as bars, with the standard deviation as the lines. Turbidity for the kit was converted from Secchi depths and therefore is expected to be less precise.

The water quality parameters were used to calculate a Water Quality Index (WQI) that classifies the state of the water on a scale for 0 to 100 (Brown et al., 1970). The WQI can be a useful tool for communicating water quality information to the public and has been used successfully in countries worldwide (Dunnette, 1979; Bhargava, 1983; House and Ellis, 1987; House, 1990; Smith, 1990; Dojildo et al., 1994; Palupi et al., 1995; Wills and Irvine, 1996; Pesce et al., 2000; Bordalo et al., 2001; Cude, 2001). The results of the sampling shown in Table 2.2 produced WQI scores in the range of 68 to 74, which qualitatively, would be fair to good quality (Mitchell and Stapp, 1995). 
A comparison between the two sampling dates (July, 2004 and January, 2005) show similarities for most of the measured analytes. However, water temperatures were cooler and the waters were far less turbid in January. A clear boundary (blue versus brown waters) was visible in January between the Mekong River and Tonle Sap/Bassac rivers. This boundary was apparent in the data (Table 2.2), where turbidity (suspended solids and secchi depth) measured in January were lower than those samples measured in July. The Mekong River does not appear to mix with the Tonle Sap and Basac rivers during the dry season. The flow reversal of the Tonle Sap is apparent in the E-coli data collected. During our July sampling, flow in the Tonle Sap was northerly, and site 2 (down stream of Phnom Penh) recorded the highest $E$-coli values $(3,300$ colonies $/ 100 \mathrm{~mL})$. During our January sampling flow in the Tonle Sap River reversed (southerly) into the Basac River, and Site 3 (down stream of Phnom Penh) recorded the highest E-coli values $(1,100$ colonies/100mL)

Table 2.2 Aquanaut Water Quality Kit results. First numbers are July, 2004 results / second numbers are January, 2005 results.

\begin{tabular}{lccccc}
\hline Analyte & Site 1 & Site 2 & Site 3 & Site 4 & Site 5 \\
\hline D.O. (ppm) & $5.5 / 5.5$ & $6 / 5$ & $6.5 / 6$ & $7 / 7$ & $7 / 6$ \\
$\begin{array}{l}\text { D.O. (\% } \\
\text { Saturation) }\end{array}$ & $70 / 68$ & $75 / 60$ & $83 / 75$ & $95 / 85$ & $90 / 75$ \\
BOD5 (ppm) & $3 / 0.5$ & $3 / 0$ & $2 / 1$ & $3 / 1$ & $3 / 0$ \\
Temperature (C) & $30.4 / 26.3$ & $32.1 / 26.6$ & $32 / 27.6$ & $32.5 / 26.5$ & $30.5 / 26.2$ \\
pH & $7 / 7$ & $7 / 7$ & $7 / 7$ & $7.5 / 7$ & $7 / 7$ \\
Hardness (ppm) & $107 / 54$ & $54 / 54$ & $72 / 56$ & $54 / 90$ & $54 / 90$ \\
Secchi Depth (ft) & $0.5 / 1.5$ & $0.5 / 1.5$ & $0.5 / 2$ & $0.3 / 4.5$ & $0.5 / 4.5$ \\
Turbidity (NTU) & $100 / 20$ & $100 / 20$ & $100 / 15$ & $125 / 5$ & $100 / 5$ \\
$\begin{array}{l}\text { Suspended Solids } \\
\text { (ppm) }\end{array}$ & $89 / 17$ & $192 / 29$ & $190 / 18$ & $188 / 5$ & $254 / 13$ \\
$\begin{array}{l}\text { Dissolved Solids } \\
\text { ppm) }\end{array}$ & $80 / 60$ & $80 / 60$ & $80 / 60$ & $80 / 130$ & $90 / 140$ \\
Total Solids (ppm) & $169 / 76$ & $272 / 89$ & $270 / 78$ & $268 / 135$ & $344 / 155$ \\
Nitrate (ppm) & $0.2 /<0.1$ & $0.1 /<0.1$ & $0.1 /<0.1$ & $0.2 /<0.1$ & $0.2 / 0.1$ \\
Phosphate (ppm) & $0.15 /<0.1$ & $<0.1 /<0.1$ & $<0.1 / 0.15$ & $0.1 /<0.1$ & $0.1 /<0.1$ \\
$\begin{array}{l}\text { E-Coli (per 100 } \\
\text { mL) }\end{array}$ & $100 / 100$ & $3300 / 100$ & $1700 / 1,100$ & $0 / 0$ & $200 / 0$ \\
\hline
\end{tabular}


Eloheimo et al. (2002) summarized water quality data collected on a monthly basis between 1995 and 2000 for locations along the Tonle Sap Lake, Tonle Sap River and Mekong River (Chruy Changvar, just upstream of Phnom Penh). Mean nitrate values in July for the Tonle Sap and Mekong River sites reported by Eloheimo et al. (2002) ranged between 0.3 and $0.35 \mathrm{mg} \mathrm{L}^{-1}$, while the phosphate phosphorus ranged from 0.03 to $0.05 \mathrm{mg} \mathrm{L}^{-}$

${ }^{1}$. These values are in general agreement with those shown in Table 2.2.

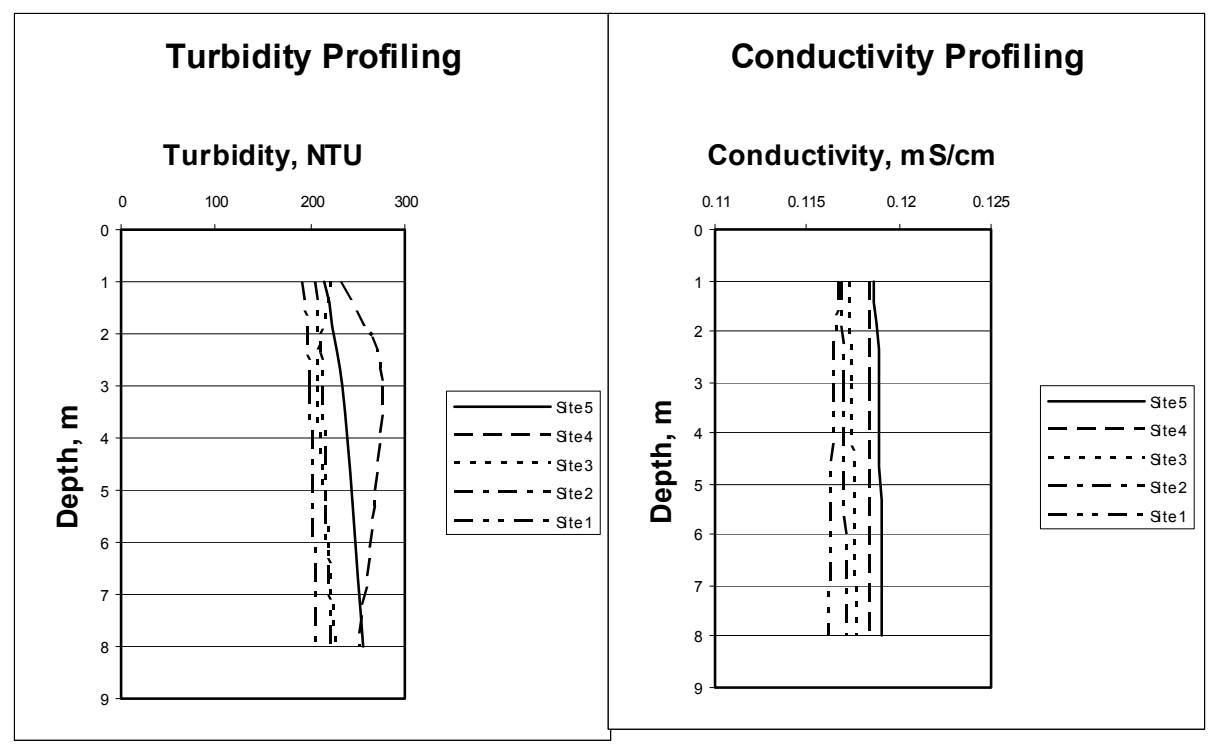

Figure 2.11 Hydrolab profiling, 7/6/2004.

Results of the Hydrolab profiling on July 6, 2004 (Figure 2.11) show that all sites on the Tonle Sap, Mekong, and Bassac Rivers were fully mixed to a depth of $8 \mathrm{~m}$ (the maximum extent of cable available for the Hydrolabs). The Mekong River sites (4 and 5) tended to have higher turbidity and conductivity than the Tonle Sap and Bassac River sites. There are various ways to visualize the Hydrolab time series data. Figure 2.12 shows an example of the 15-minute data for the period 9/10-9/18/04, during the peak of the rainy season. The temperature data in Figure 2.12 show a clear diurnal trend. Dissolved oxygen levels are high, which is encouraging. Because of 
runoff events, turbidity also exhibits two separate peaks. The limit of measurement for the turbidity sensor is $1,000 \mathrm{NTU}$ and this is the reason that the time series appears clipped starting on $9 / 13 / 04$. Turbidity is related to suspended solids concentration, although because turbidity is an optical property that can be affected by particle shape and size distribution, mineral composition, and presence of humic acid, the relationship will vary from location to location (Lewis, 1996; Davies-Colley and Smith, 2001; Sun et al., 2001; Irvine et al., 2002). We have begun to develop turbidity-suspended solids rating curves (e.g. Figure 2.13) that eventually will be used to assess sediment mass loadings. Eloheimo et al. (2002) reported monthly mean suspended solids concentrations in the Tonle Sap and Mekong River sites noted above, as ranging from lows of $<20 \mathrm{mg} \mathrm{L}^{-1}$ for the months of December through April, to highs of $125-300 \mathrm{mg} \mathrm{L}^{-1}$ in the rainy season months of August and September. The Hydrolab data also can be examined on a mean basis, as shown in Table 2.3. Again, the dissolved oxygen levels are good, although the Tonle Sap tended to have higher levels than the Mekong River. On average, the turbidity for this period of time tended to be higher at the Mekong River site, as was the conductivity (Table 2.3).

In conclusion, the water quality in the Mekong, Tonle Sap, and Bassac Rivers in the area of Phnom Penh was surprisingly good. Turbidity can be high, which may impact the taste of water when withdrawn for domestic distribution (MRD, 2002) and therefore should be settled or treated prior to distribution. Of greatest concern are the E. coli levels in the Bassac River. Drinking water pump stations are interspersed with sewage discharges, particularly on the eastern bank of the river in the vicinity of sample site 3 and this increases the risk of infection by waterborne diseases in that area.

Table 2.3 Mean and standard deviation (in bracket) of Hydrolab parameters, 8/16/2004-10/15/2004.

\begin{tabular}{lccccc}
\hline Sample Site & Temp., C & $\begin{array}{c}\text { Cond., mS } \\
\mathrm{cm}^{-1}\end{array}$ & $\begin{array}{c}\text { D.O., mg } \\
\mathrm{L}^{-1}\end{array}$ & $\mathrm{pH}$ & $\begin{array}{c}\text { Turbidity, } \\
\text { NTU }\end{array}$ \\
\hline $\begin{array}{l}\text { Russey Keo (Tonle Sap } \\
\text { River) }\end{array}$ & 29.1 & 0.0951 & 5.76 & 7.23 & 297 \\
& $(0.89)$ & $(0.004)$ & $(0.43)$ & $(0.70)$ & $(134)$ \\
Preak Leap (Mekong River) & $\begin{array}{c}28.2 \\
(0.61)\end{array}$ & $\begin{array}{c}0.1132 \\
(0.007)\end{array}$ & $\begin{array}{c}5.55 \\
(0.28)\end{array}$ & $\begin{array}{c}7.66 \\
(0.14)\end{array}$ & $\begin{array}{c}(116) \\
\end{array}$ \\
\hline
\end{tabular}



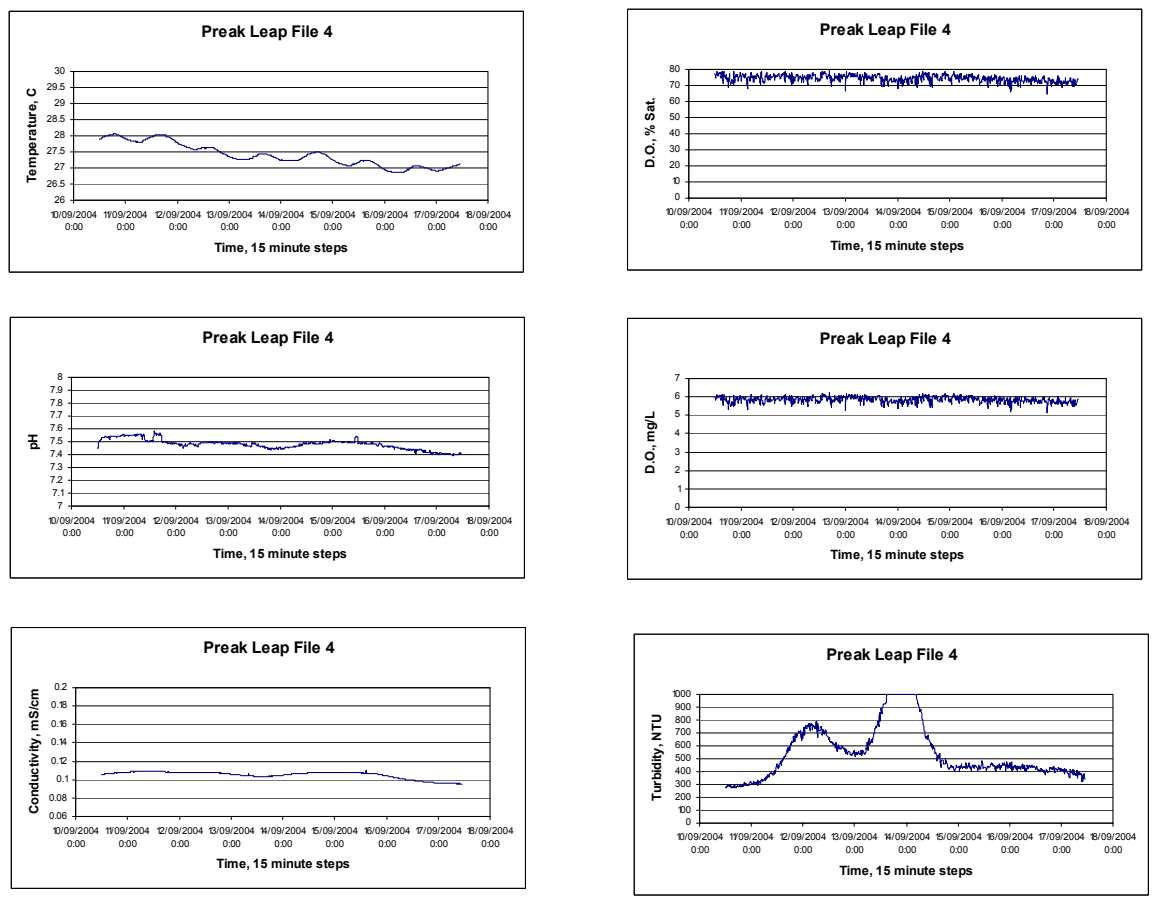

Figure 2.12 Hydrolab results, 15 minute time steps, Preak Leap site (Mekong River).

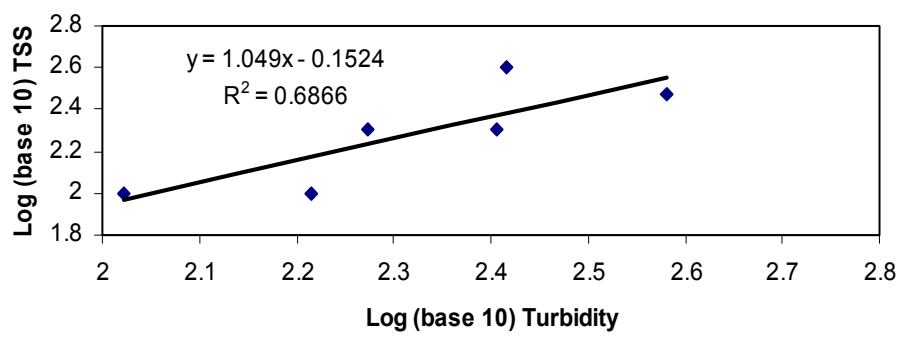

Figure 2.13 Total suspended solids (TSS)/turbidity rating curve, Russey Keo (Tonle Sap River) site. 


\subsection{Institutional Responsibilities for Water Quality Management}

In Cambodia, there are multiple government agencies that have some responsibility in managing water resources, just as there are in the U.S. The five principal agencies are the Ministry of Industry, Mines, and Energy (MIME); Ministry of Rural Development (MRD); Ministry of Water Resources and Meteorology (MOWRAM); Ministry of Health (MOH); and Ministry of Environment (MOE). MIME is responsible for the development of urban water supply systems outside of Phnom Penh, including monitoring drinking water quality, establishing water tariffs, and providing technical assistance to public and private drinking water suppliers (the Phnom Penh Water Supply Authority is responsible for water supply within the city). MRD is responsible for community water supply in rural areas, including oversight of basic water quality analysis. MOWRAM is responsible for the overall management of Cambodia's water resources, although most of its activities have focused on the lower Mekong basin. The $\mathrm{MOH}$ role in water primarily focuses on research related to waterborne diseases, while the MOE is responsible for the conservation of biodiversity and environmental aspects of water pollution as it relates to the protection of human health (MRD, 2002).

These agencies have a short history. The MOE, for example, was created in 1993 and the Sub-decree on Water Pollution Control was passed in 1999. The Sub-decree established a permit process for industrial effluent discharge, including ministry monitoring procedures and guidelines for effluent quality. Article 9 of the Sub-decree notes that "The discharge of sewage from dwelling and public buildings into public water areas without passing through public sewerage systems or other treatment systems shall be strictly prohibited". The essence of a water quality management framework has been established, including the necessity and methodology to conduct Environmental Impact Assessments (e.g. Im, 2000).

Unfortunately, at this point in time, several factors continue to negatively impact the effectiveness of water quality management. First, there continues to be a shortage of technical personnel capable of carrying out water quality mandates. In part, this is related to limited opportunities within the higher education system. The Royal University of Phnom Penh, for example, only recently (2000) established a Department of Environmental Science. Furthermore, because public service wages are relatively low ( $\$ 40 /$ month), trained personnel often are lured away by the higher wages offered by large 
NGOs. Second, laboratory capabilities are limited, and although there are water quality guidelines for analytes such as DDT, dieldrin, benzene, PCBs, total and organic mercury, lead, chromium, and arsenic, there is some question whether the detection limits in the range of $\mu \mathrm{g} \mathrm{L}^{-1}$ can be reached in government laboratories. Third, the relatively limited government budgets (which are sourced to a great extent from donor countries, as noted above) mean that there is keen competition between agencies for programmatic funding. This results in agencies guarding the funding they get and negatively impacts inter-agency cooperation. Constrained budgets also mean that it is difficult for government agencies to enforce regulations.

\subsection{Conclusion}

Phyrun (1996) noted the same tragedy that destroyed Cambodian infrastructure, institutions, and tore at the social fabric of the country, paradoxically protected the country from many of the environmental problems encountered in developed countries. However, development is increasing in Cambodia and it is important that the country be able to make informed decisions to manage this development sustainably. Education and training at all levels clearly is an important theme in this chapter. Education outreach at the local level on issues ranging from basic sanitation to appropriate handling and use of pesticides is essential. This requires strengthening the education system as a whole, from teacher training, to primary, secondary, and university education, to training of government personnel.

Clearly, economic conditions within Cambodia continue to present challenges to managing water resources. Government agencies compete for scarce funding and this hinders interaction and coordination. Limited operational funding, laboratory capability, and field expertise also means that agencies are challenged in monitoring the environment and enforcing environmental laws.

Donor countries must be sensitive to the varying needs within the country. As noted in the areas of sanitation and drinking water, the widespread distribution of low cost, low tech solutions may be most effective in improving health conditions, particularly in rural areas. From a water quality perspective, the three biggest concerns for Cambodia are waterborne diseases associated with bacterial, viral, and parasitic infection; 
high levels of arsenic in the groundwater of some provinces; and the inappropriate use of pesticides.

\section{References}

Abedin, M.J., Cresser, M.S., Meharg, A.A., Feldmann, J. and Cotter-Howells, J. 2002 a. Arsenic accumulation and metabolism in rice (Oryza sativa L.). J. Environmental Science and Technology, 36:962-968.

Abedin, M.J., Cotter-Howells, J. and Meharg, A.A. 2002b. Arsenic-uptake and accumulation in rice (Oryza sativa L.) irrigated with contaminated water. Plant and Soil, 240: 311-319.

Abedin M.J. and Meharg, A.A. 2003. Relative toxicity of arsenite and arsenate on germination and early seedling growth of rice (Oryza sativa L.). Plant and Soil, 243: 57-66.

Abernathy, C.O., Thomas, D.J. and Calderon, R.L. 2003. Health effects and risk assessment of arsenic. J. Nutrition, 133(5):1536S-8S.

Agusa, T., Kunito, T., Kubota, R., Monirith, I., Tanabe, S. and Tana, T.S. 2002. Arsenic pollution in Cambodia. Biomed. Res. Trace Metals, 13:254-255.

Albanese, M. 2002. Angkor: Splendors of the Khmer Civilization, White Star Publishers, Vercelli, Italy.

Ayres, D.M. 2000. Anatomy of a Crisis, Education, Development and the State in Cambodia, 1953-1998, Silkworm Books, Chiang Mai, Thailand.

Berg, M., Tran, H.C., Nguyen, T.C., Pham, H.V., Schertenleib, R. and Giger, W. 2001. Arsenic contamination of groundwater and drinking water in Vietnam: A human health threat. Environ. Sci. Technol. 35(13):2621-2625.

Bhargava, D.S. 1983. Use of a water quality index for river classification and zoning of Ganga River. Environmental Pollution (Series B), 6: 51-67.

Bishayi, B. and Sengupta, M. 2003. Intracellular survival of Staphylococcus aureus due to alteration of cellular activity in arsenic and lead intoxicated mature Swiss albino mice. Toxicology, 184(1):31-39.

Bordalo, A.A., Nilsumranchit, W. and Chalermwat, K. 2001. Water quality and uses of the Bangpakong River (Eastern Thailand). Water Research, 35(15): 3635-3642.

Brown, R.M., McClelland, N.I., Deininger, R.A. and Tozer, R.G. 1970. A water quality index - do we dare? Water and Sewage Works, 117: 339-343.

Chakraborti, D., Mukherjee, S.C., Pati, S., Sengupta, M.K., Rahman, M.M., Chowdhury, U.K., Lodh, D., Chanda, C.R., Chakraborti, A.K. and Basu, G.K. 2003. Arsenic groundwater contamination in Middle Ganga Plain, Bihar, India: A future danger? Environmental Health Perspectives, 2003 Jul, 111(9):1194-201.

Chenda, H., Vuthy, U., Narith, C.H., Pithoura, H., Rithy, H., Chantha, I. and Vanny, P. 2002. Agro-Chemical Use in Cambodia, Case Study in Tramkak and Traing District, Takeo Province, Report, National Capacity Development Project - Cambodia, Task Force 2, Royal Government of Cambodia. 
Cude, C.G. 2001. Oregon water quality index: A tool for evaluating water quality management effectiveness. Journal of the American Water Resources Association, 37(1): 125-137.

Davies-Colley, R.J. and Smith, D.G. 2001. Turbidity, suspended sediment, and water clarity: A review. Journal of the American Water Resources Association, 37(5): 1085-1101.

de Esparza, M.L.C. 2003. The problem of arsenic in drinking water in Latin America. In Aquatic Arsenic Toxicity and Treatment. eds. Tom Murphy and Jay Guo, Backhuys Press. 186p.

de Gieter, M., Leermakers, M., Van Ryssen, R., Noyen, J., Goeyens, L. and Baeyens, W. 2002. Total and toxic arsenic levels in north sea fish. Arch Environ Contam Toxicol., 43(4):406-17.

de Walque, D. 2004. The Long-Term Legacy of the Khmer Rouge Period in Cambodia. World Bank Policy Research Working Paper 3446.

Dojlido, J., Raniszewski, J. and Woyciechowska, J. 1995. Water quality index application for rivers in Vistula River Basin in Poland. Water Science and Technology, 30(10): 57-64.

Dunnette, D.A. 1979. A geographically variable water quality index used in Oregon. Journal Water Pollution Control Federation, 51(1): 53-61.

Edmonds, J.S., and Francesconi, K.A. 1993. Arsenic in seafoods: human health aspects and regulations. Marine Pollut. Bull., 26(12):665-674.

Eloheimo, K., Hellsten, S., Jantunen, T., Jozsa, J., Kiirikki, M., Lauri, H., Koponen, J., Sarkkula, J., Varis, O. and Virtanen, M. 2002. Water Utilization ProgramModelling of the Flow Regime and Water Quality of the Tonle Sap, Data Report, MRCS/WUP-FIN Report, Mekong River Commission, Phnom Penh.

Environmental Justice Foundation, 2002. Death in Small Doses: Cambodia's Pesticide Problems and Solutions, Environmental Justice Foundation, London, UK.

Feldman, P.R. and Rosenboom, J-W. 2001. Cambodia Drinking Water Quality Assessment, Final Report, Report for WHO.

Fletcher, R., Evans, D. and Kummu, M. 2003. The dynamics of water management of Angkor, Cambodia, $9^{\text {th }}$ to $16^{\text {th }}$ century. Proceedings, $3^{\text {rd }}$ Conference of IWHA, Alexandria, Egypt.

Gerdsen, R., Stockfleth, E., Uerlich, M., Fartasch, M., Steen, K.H. and Bieber, T.. 2000. Papular palmoplantar hyperkeratosis following chronic medical exposure to arsenic: human papillomavirus as a co-factor in the pathogenesis of arsenical keratosis? Acta dermato-venereologica, 80(4):292-3.

Gottesman, E. 2003. Cambodia after the Khmer Rouge, Inside the Politics of Nation Building, Silkworm Books, Chiang Mai, Thailand.

Guo, H-R. 2003. Arsenic in Drinking Water and Cancers in Taiwan. In Aquatic Arsenic Toxicity and Treatment. eds. Tom Murphy and Jay Guo, Backhuys Press. 186p.

House, M.A. 1990. Water quality indices as indicators of ecosystem change. Environmental Monitoring and Assessment, 15: 255-263.

House, M.A. and Ellis, J.B. 1987. The development of water quality indices for operational management. Water Science and Technology, 19(9): 145-154.

Im, S. 2000. Country Report on Environmental Impact Assessment, Ministry of Environment, Phnom Penh. 
Irvine, K.N., Somogye, E.L. and Pettibone, G.W. 2002. Turbidity, suspended solids, and bacteria relationships in the Buffalo River watershed. Middle States Geographer, 35: 42-51.

Irvine, K.N., Vermette, S.J., Tang, T., Sampson, M. and Murphy, T.P. 2004. Partnering to provide water quality and GIS training in Cambodia. Proceedings, $25^{\text {th }}$ Asian Conference on Remote Sensing, Asian Association on Remote Sensing, Bangkok.

Jalal, K.F. 2003. Water and Sanitation in Asia: A Status Report. Report for the United Nations Economic and Social Commission for Asia and the Pacific, Bangkok.

JICA (Japan International Cooperation Agency), 1999. The Study on Drainage Improvement and Flood Control, Vol. 2, Municipality of Phnom Penh.

Justice, R. and Irvine, K. 2005. Survey of pesticide and fertilizer use in Cambodia's Stung

Chinit River Watershed - Preliminary Results. Abstracts, Association of American Geographers, Middle States Division, Annual Meeting.

Kiernan, B. 1999. The Pol Pot Regime, Race, Power, and Genocide in Cambodia under the

Khmer Rouge, 1975-1979, Silkworm Books, Chiang Mai, Thailand.

Kummu, M. 2003. The natural environment and historical water management of Angkor, Cambodia. The Fifth World Archeological Congress, Washington, D.C.

Kummu, M., Sarkkula, J., Koponen, J. and Nikula, J. 2005. Ecosystem Management of Tonle Sap Lake: Integrated Modeling Approach. Paper presented at the workshop on Integrated Water Resource Management on Tonle Sap Lake, Feb. 1-2, Royal University of Phnom Penh.

Lewis, J. 1996. Turbidity-controlled suspended sediment sampling for runoff-event load estimation. Water Resources Research, 32(7): 2299-2310.

Little, D., Borin, C., Rigg, J. and Dalsgaard, A. 2003. State-of-the-System Report: Cambodia. Production in Aquatic Peri-Urban Systems in Southeast Asia, Report Series No. 2/2003.

Le, X. C., Lu, X. and Li, X.F.. 2004. Arsenic speciation. Anal. Chem., Jan. 27a-31a.

Meharg, A. A. and Rahman, M. 2003. Arsenic contamination of Bangladeshi paddy field soils: implications for rice contribution to arsenic consumption. Environmental Science and Technology, 37(2):229-34.

Mekong River Commission, 2003. State of the Basin Report: 2003, Executive Summary, Mekong River Commission, Phnom Penh.

Milton, A.H., Hasan, Z., Rahman, A. and Rahman, M. 2003. Non-cancer effects of chronic arsenicosis in Bangladesh: preliminary results. Journal of Environmental Science and Health. Part A, Toxic/hazardous Substances \& Environmental Engineering, 2003 Jan, 38(1):301-5.

Mitra, A.K., Bose, B.K., Kabir, H., Das, B.K. and Hussain, M. 2002. Arsenic-related health problems among hospital patients in southern Bangladesh. Journal of Health, Population, and Nutrition, 2002 Sep, 20(3):198-204.

Mitchell, M.K. and Stapp, W.B. 1995. Field Manual for Water Quality Monitoring, An Environmental Education Program for Schools, Thomson-Shore, Inc., MI.

Monirith, I., Nakata, H., Watanabe, M., Takahashi, S., Tanabe, S. and Tana, T.S. 2000. Organochlorine contamination in fish and mussels from Cambodia and other Asian countries. Water Science and Technology, 42(7-8): 241-252. 
MRD (Ministry of Rural Development), 2002. Drinking Water Quality in Cambodia, Country Report, Department of Rural Water Supply.

Mukherjee, N. 2002. Learning What Works for Sanitation, Revisiting Sanitation Successes in Cambodia, Water and Sanitation Program East Asia and the Pacific, Report, Jakarta.

Muong, S. 2004. Avoiding Adverse Health Impacts from Contaminated Vegetables: Options for Three Wetlands in Phnom Penh, Cambodia, Economy and Environment Program for Southeast Asia, Research Report No. 2004-RR5, Singapore.

Murphy, T. P. and Guo, J. 2003. An introduction of arsenic toxicity and its management. In Aquatic Arsenic Toxicity and Treatment. eds. Tom Murphy and Jay Guo, Backhuys Press. 186p.

National Institute of Statistics, 2000. Cambodia Demographic and Health Survey, 2000. National Institute of Statistics, Phnom Penh.

Oremland, R.S. and Stolz, J. F. 2003. The ecology of arsenic. Science, 300:939-944.

Palupi, K., Sumengen, S., Inswiasri, S., Agustina, L., Nunik, S.A., Sunarya, W. and Quraisyn, A. 1995. River water quality study in the vicinity of Jakarta. Water Science and Technology, 31(9): 17-25.

Paul, B.K. and De, S. 2000. Arsenic poisoning in Bangladesh: A geographic analysis. Journal of the American Water Resources Association, 36(4): 799-809.

Pavittranon, S., Sripaoraya, K., Ramchuen, S., Kachamatch, S., Puttaprug, W., Pamornpusirikul, N., Thaicharuen, S., Rujiwanitchkul, S. and Walueng, W. 2003. Laboratory case identification of arsenic in Ronpibol Village, Thailand (2000-2002). J. Environ. Sci. Health, A38:213-221.

Pesce, S.F. and Wunderlin, D.A. 2000. Use of water quality indices to verify the impact of Cordoba City (Argentina) on Suquia River. Water Research, 34(11): 2915-2926.

Phyrun, U. 1996. The environmental situation in Cambodia, policy and instructions. In A. Vlavianos-Arvanitis, ed., Biopolitics, the Bio-Environment, and Bio-Culture in the Next Millennium, Vol. V, Biopolitics International Organization, Athens.

Safiuddin M. and Karim, M. 2003. Water resources management in the remediation of groundwater arsenic contamination in Bangladesh. In Aquatic Arsenic Toxicity and Treatment. eds. Tom Murphy and Jay Guo, Backhuys Press. 186p.

Sinath, C. 2002. Investment in land and water in Cambodia. In Proceedings of the Regional Consultation, Bangkok, Thailand, 2001, Food and Agriculture Organization of the United Nations.

Smith, D.G. 1990. A better water quality indexing system for rivers and streams. Water Research, 24(10): 1237-1244.

Sotham. S. 2004. Small-scale gold mining in Cambodia - a situation assessment. Oxfam America. $37 \mathrm{p}$.

Stute, M. and Zheng, Y. Project 5: Arsenic Mobilization in Bangladesh Ground Water. Drinking Water, an International Conference, Columbia University, November 2627, 1999.

Sun, H., Cornish, P.S. and Daniell, T.M. 2001. Turbidity-based erosion estimation in a catchment in South Australia. Journal of Hydrology, 253: 227-238.

Sun, S.Q. 1987. Etiology of lung cancer at the Gejiu tin mine, China. Int. Symp. Princess Takamatsu Cancer Res. Fund 18:103-115. 
United Nations, 2003. An Investment Guide to Cambodia Opportunities and Conditions, New York.

U.S. EPA. 2003. Technical Summary of Information on the Bioaccumulation of Arsenic in Aquatic Organisms. U.S. EPA, Washington, DC. 20460. EPA-822-R-03-032.

World Bank, 2003. Cambodia Environment Monitor 2003, World Bank Phnom Penh Office, Cambodia.

Wills, M. and Irvine, K.N. 1996. Application of the National Sanitation Foundation water quality index to the Cazenovia Creek pilot watershed management study. Middle States Geographer, 29: 95-104.

Yee, P., Edgett, R. and Eberhardt, A. 1993. Great Lakes-St. Lawrence River Regulation, What it Means and How it Works, Environment Canada and U.S. Army Corps of Engineers.

Yu, W.H. 2003. Arsenic in groundwater in Bangladesh: a geostatistical and epidemiological framework for evaluating health effects and potential remedies. Water Resources Res., 39(6)1146-1163.

Zhang, H. 2003. Arsenic pollution and arseniasis in Hetao Area, China. In Aquatic Arsenic Toxicity and Treatment. eds. Tom Murphy and Jay Guo, Backhuys Press. $186 \mathrm{p}$ 